Annals of Warsaw University of Life Sciences - SGGW

Land Reclamation No 39, 2008: 121-127

(Ann. Warsaw Univ. of Life Sci. - SGGW, Land Reclam. 39, 2008)

\title{
The silting influence on the capacity of the Krzywaniec reservoir
}

\author{
MARIAN MOKWA, BEATA MALCZEWSKA \\ Wrocław University of Environmental and Life Science
}

\begin{abstract}
The silting influence on the capacity of the Krzywaniec reservoir. The Krzywaniec reservoir is a part of Dychów complex hydraulic engineering, and it was created as a damming up water of the Bóbr river in $42+700 \mathrm{~km}$ to wave elevation $73.30 \mathrm{NN}$. The river valley was divided by three span gate weir and tide gate to derivation channel to ESP Dychów. The Krzywaniec reservoir is currently silted up so that the probable water surface $\mathrm{Q}_{1 \%}$ is going to reach reservoir site embankment which means it poses the flood risk on surrounding area. The authors present restoring the initial situation on Krzywaniec reservoir, and estimated the reduction of flood depending on method of declogging the reservoir using computer simulation performed in HEC-RAS.
\end{abstract}

Key words: storage reservoirs, hydropower stations, derivation channel, sediment transport, silting of storage reservoirs.

\section{INTRODUCTION}

The reservoir silting up process is a huge problem for non-failure operation. It has also negative influence on retention capacity and consequently it contributes to the flood risk. Storage reservoirs gradually loose their capacity due to sedimentation in time. Controlling reservoir silting is a major objective of planning, designing and operation engineers. Therefore planners should take into consideration how to preserve capacity of reservoirs.

The Krzywaniec reservoir is a part of Dychów complex hydrotechnical system, and it was created as a damming up of water the Bóbr river in $42+700 \mathrm{~km}$ to damming up elevation $73.30 \mathrm{NN}$. The river valley was divided by three span gate weir and tide gate to derivation channel to Dychów hydro-electric power station (ESP). The Krzywaniec stage of fall is subsume to II class hydraulic engineering object. Dychów hydrotechnical system is composes by object functionally connected to ESP (Fig. 1.) and consists of the following elements (Studium regulacji... 1985, Studium techniczne... 1990):

- ESP Dychów (hydro-electric power station) - flow $\mathrm{Q}=330 \mathrm{~m}^{3} / \mathrm{s}$, with short lower channel connected to Bóbr river in $7.5 \mathrm{~km}$,

- Upper reservoir in Dychów,

- Derivation channel,

- Krzywaniec reservoir in Bóbr valley with weir and water intake in $42.7 \mathrm{~km}$,

- Bóbr "dry river - bed" from Krzywaniec weir to Dychów ESP.

The backwater of Krzywaniec weir was reaching weir in Nowogród Bobrzański in $48+400 \mathrm{~km}$ originally, but at present the damming up reaches stabilizing stage of fall in $47+300 \mathrm{~km}$ of Bóbr river, whose overfall crest is on $73.5 \mathrm{~m} \mathrm{NN}$. The need to protect adjoin sites forced to build embankment with spacing about of $250 \mathrm{~m}$. The left embankment protects 


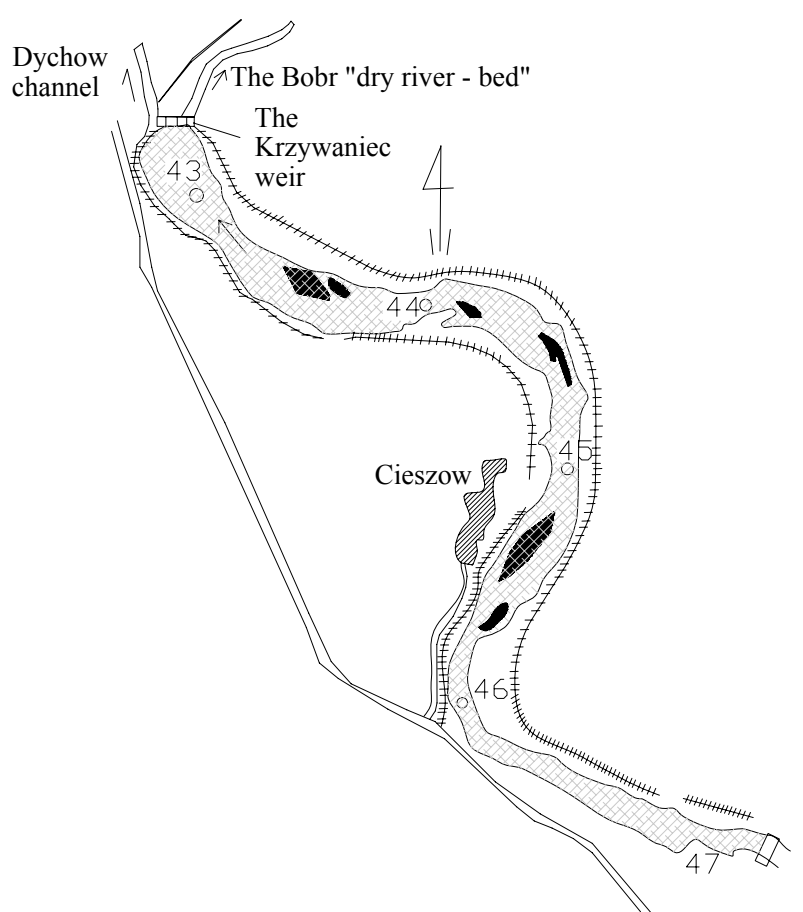

FIGURE 1. Scheme of the Dychów hydrotechnical system

the river meander and Cieszów village. The right embankment is embanked up till $46.6 \mathrm{~km}$ and protects agricultural sites and Nowogród strip mine as well as the weir from uncontrolled outflow (Zbiornik Krzywaniec 1997).

The characteristic water levels for hydraulic engineering object of this class are as follows: base flow $\mathrm{Q}_{1 \%}=1100 \mathrm{~m}^{3} / \mathrm{s}$, control flow $\mathrm{Q}_{0.3 \%}=1380 \mathrm{~m}^{3} / \mathrm{s}$ - based on water resource management from 2005 (Koncepcja odtworzenia... 2005).

The intense silting up process has been observed at The Bóbr river has been transporting rubble to Krzywaniec reservoir for years. The reservoir capacity changes were induced by sedimentation and erosion as well as mining. The reservoir was designed to hold $4 \mathrm{mln} \mathrm{m}^{3}$, its storage capacity (before silting up) was
$2.4 \mathrm{mln} \mathrm{m}^{3}$, usable capacity $1.14 \mathrm{mln} \mathrm{m}^{3}$, maximal depth $5.90 \mathrm{~m}$, the average depth $3.85 \mathrm{~m}$, water area of reservoir 5.9 ha (at NPP) (Operat wodno-prawny 1992). If the Krzywaniec reservoir was naturally silted up, the reservoir bowls would be filled up in about 48 years. The history of Krzywaniec silting up is described in paper (Mokwa et al. 2004).

Although sedimentation of a reservoir is usually a slow process, the Krzywaniec reservoir is being silted up at present so that the probable water surface $\mathrm{Q}_{1 \%}$ is going to reach reservoir both side embankment. It means that in such case water bursts the banks and both sides of the Bóbr valley are going to be inundated - left side with the Cieszów village as well as right side with Podgórzyce and Turów villages. The condition of Krzy- 
waniec reservoir is going to affect the siltation of water intake and the derivation channel.

This problem is considered because of systematic silting up therefore the flooding risk.

The main purpose of this article is to present the forecast of silting up carried out on Krzywaniec reservoir and possible method of solving the problem.

There have been developed series of expertises which point out the necessity of declogging the reservoir.

\section{MATERIAL AND METHODS}

A sedimentary material (consisting of very fine particles intermediate in size between sand and clay) silts up the reservoir. This process depends on the amount of silt carried by the river which feeds it as well as on the rate of soil erosion in the river's catchment area. The Bóbr river is built over by hydro-engineering objects (dry reservoir, flood control reservoirs, weirs, stages of fall), therefore the cross fall have been reduced and what in turn have limited the erosion of river-bed, bed load and suspended load movement. The change of reservoir floor is caused by natural sedimentation and erosion but also by human activity - aggregate output.

The Krzywaniec reservoir has been depleted by sedimentation of particles at diameter ranges from $2.6 \mathrm{~mm}$ to $0.4 \mathrm{~mm}$. The bed dynamics during the history of the Krzywaniec reservoir was analyzed by Glowski et al. (2004). They observed the segregation of the bed material through partial washout fatter fractions.

A few methods have been worked out for The Krzywaniec reservoir modernization enclosing following solutions:
- The reservoir bowl at its current condition with bank superstructure,

- Maximum dredge of the reservoir bowl,

- Removal of islands form the reservoir bowl.

The analysis of restoring Krzywaniec reservoir conception for leading the flooding water was based on:

- dredging the Krzywaniec reservoir to make it deeper,

- increasing the present site embankment height and building new bund,

- combination of above mentioned solutions - dredging the reservoir to make it deeper and embankment rebuilding. The basis of calculation was the cross-section of core reservoir from 1967, that is - before the reservoir was flowed, water surface level for $\mathrm{Q}_{1 \%}=1100 \mathrm{~m}^{3} / \mathrm{s}$. and average roughness coefficient $\mathrm{n}=0.03$.

\section{RESULTS AND DISCCUSION}

In this study, we use a hydraulic model to create estimates of discharge based on steady flow and the HEC-RAS v. 3.0 modelling package was used for this purpose. The objectives were to study the nature of the flow in the river and to investigate the sediment transport patterns in the river for suspended sediment deposited during flood-induced inundation of the floodplain.

The entire capacity of Krzywaniec reservoir was silted up in the 70th. The history of its silting up was presented in paper (Mokwa 2004). The intensity of silting up was estimated to 50 thousand $\mathrm{m}^{3}$ per year, and in Krzywaniec reservoir bowl accumulated about 2-3 $\mathrm{mln} \mathrm{m}^{3}$ of sediments. 
The flood in 1977, 1981 and 1997 and desilting work had small influence on present condition of Krzywaniec reservoir. The bed load transport in 1977, 1979, 1990 years is presented in Figure 2.

In order to estimate possible solution of the problem of the Krzywaniec reservoir silting a couple alternative designings were calculated.
The estimated amount of siltation is about $40000 \mathrm{~m}^{3}$. Unfortunately during a freshet only $5000 \mathrm{~m}^{3}$ is rinsed out, which means that $35000 \mathrm{~m}^{3}$ should be removed from the reservoir bowl.

The calculation and economic estimation was made for presented solution variant for $Q_{\max 1 \%}=1100 \mathrm{~m}^{3} / \mathrm{s}$ (see Figs $3,4)$. The loss of energy from friction

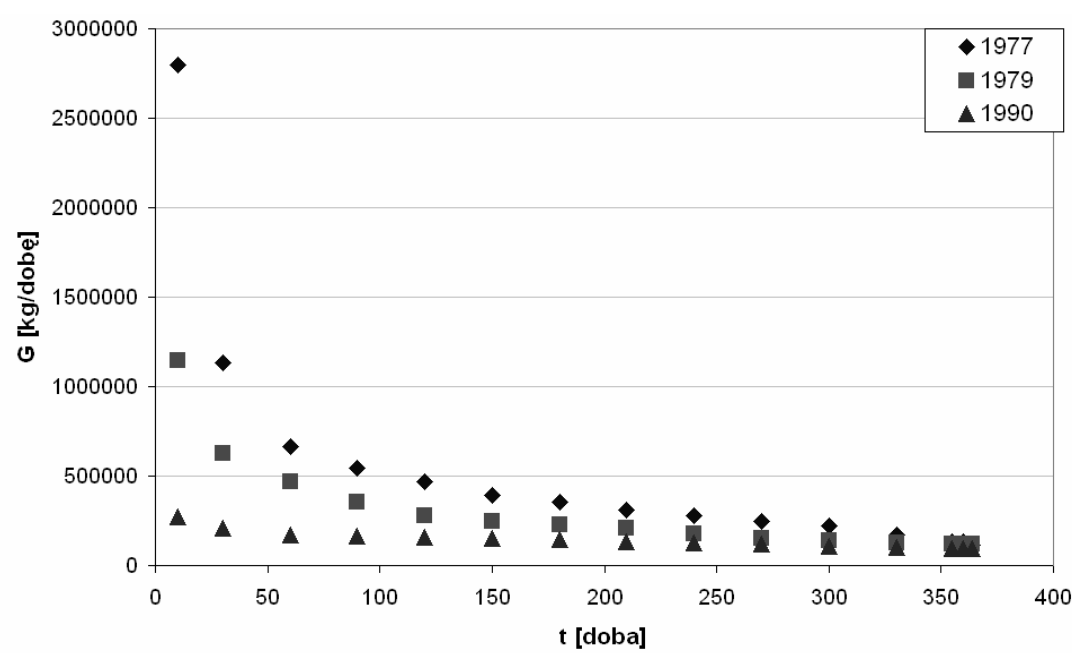

FIGURE 2. The bed load transported in Bóbr river, the Krzywaniec reservoir in 1977, 1979, 1990

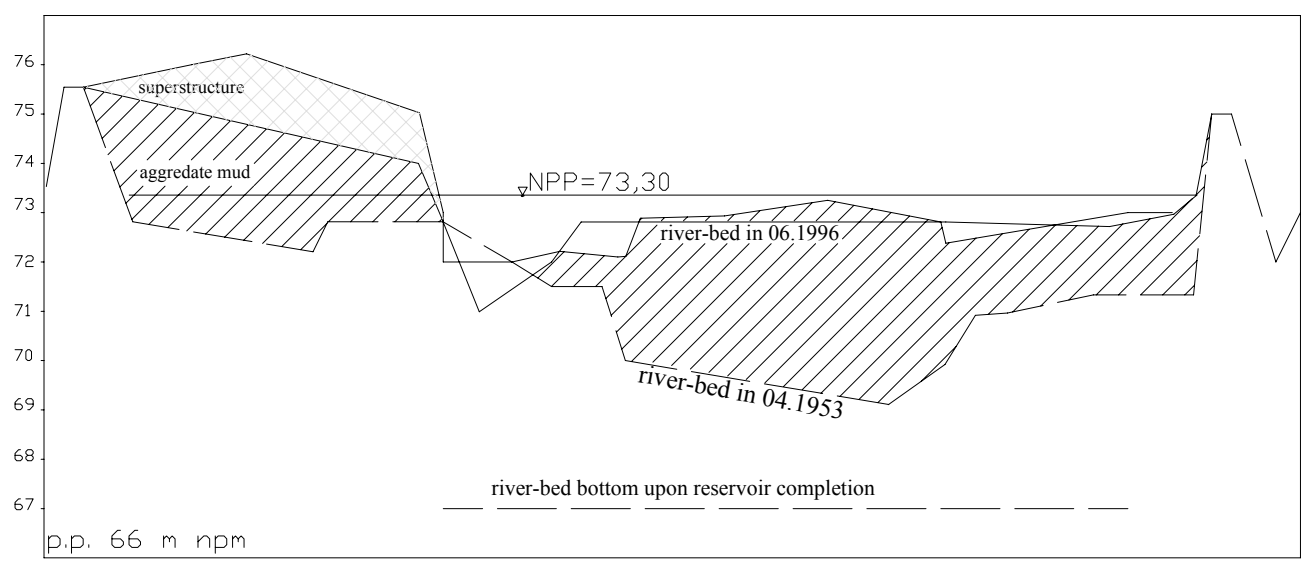

FIGURE 3. The cross-section of Krzywaniec reservoir 


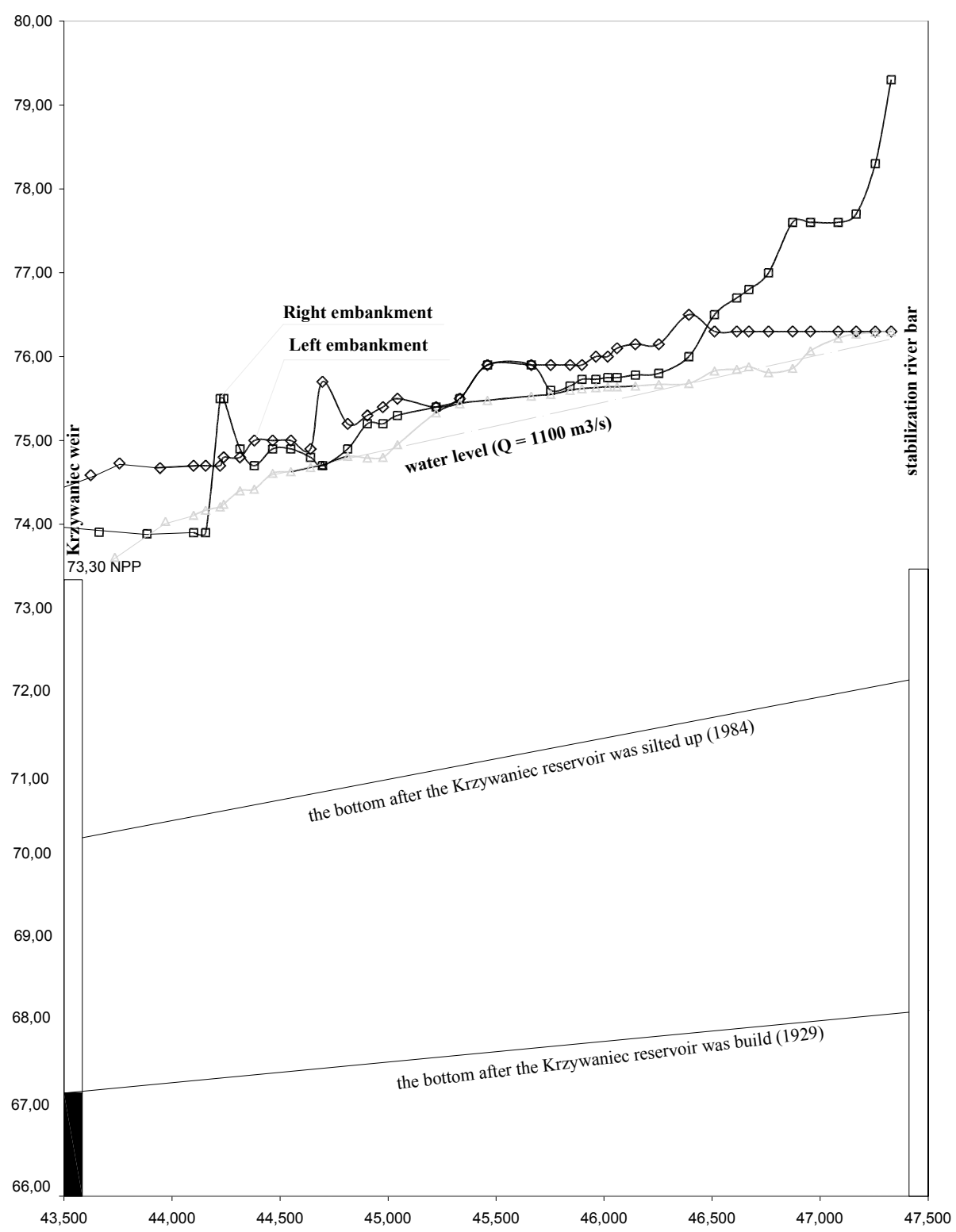

FIGURE 4. The longitudinal section of Krzywaniec reservoir

is calculated between successive valley cross-section and determines the changes in downstream water level. Modelling results show the possible solution of the problem.
The bottom of the Krzywaniec reservoir was calculated due to silting in and loss of conveyance capacity in time. The proposed canal cross-section has the bottom elevation set as it was in 1967. 
The current condition of Krzywaniec reservoir is presented in Figure 3. The reservoir is silted up at present so the probable surface of water $\mathrm{Q}_{1 \%}$ is bursting the banks.

\section{Scenario I}

The first alternative design was based on following assumption:

- Krzywaniec reservoir preparation in order to carry $Q_{\max }=1100 \mathrm{~m}^{3} / \mathrm{s}$ with annual affluent rubble removal from reservoir bowl. The amount of removed rubble is calculated to 30 to 50 thousand $\mathrm{m}^{3}$.

- Heighten the top of levee side barrier with preserve of present state of reservoir bowl at the same time (to regulate tand density on island, what has significant influence on flow WW) and regulation river-bed.

This solution is ecological and allowed to rise NPP to wave elevation $73.60 \mathrm{~m}$ n.p.m. - it is about $30 \mathrm{~cm}$ which increase water reserve for Dychów hydro - electic power station about $300000 \mathrm{~m}^{3}$. This is $100 \mathrm{~m}^{3} / \mathrm{s}$ water inflow for 50 minutes. The main drawback of this solution is major river bed annual dredging (30-50 thousand $\mathrm{m}^{3}$ rubber) and flood bank cleaning.

\section{Scenario Ib}

The hydraulic calculation was made for following assumption:

- heightening control intersection in order to carry $\mathrm{Q}_{\max }=1100 \mathrm{~m}^{3} / \mathrm{s}$,

- establish the cross-section shape and bottom level.

This is not ecological solution because it induces entire middle rampart, destruction greater dredging than above mentioned.

\section{Scenario II}

This alternative design was based on following assumption:
- Reconstruction initial condition of the reservoir bowl (liquidation Krzywaniec stage of fall and building a new stabilization stage).

The reservoir bowl is enable to carry the flow not bigger than $1116 \mathrm{~m}^{3} / \mathrm{s}$, needs to dredge above $2000000 \mathrm{~m}^{3}$ rubber, repair the embankments in this case. This solution allowed to reservoir operate for 30 to 50 years, without dredging.

\section{Scenario III}

This alternative design was based on following assumption:

- Construction of recreation - compensatory reservoir which would be bigger than current one, because it would be extended with the area of Cieszów village and right sided area exploited for aggregate.

This solution is too much expensive and has no community approval.

\section{CONCLUSION}

The siltation of the reservoir is a natural process and it should be forecasted during reservoir designing. The possibility of reservoir capacity decreasing should be considered with alternative designing allowing to lead flood water as well as with silt-clearing methods, based on the present sediment transport rate.

The conception choice has to be made considering both economic and ecological condition.

The silt has flowed through the river every year, raising the level of the riverbed. This paper presents conception of reconstruction to initial situation on Krzywaniec reservoir.

Results indicate that sediment deposited on flood plain in the past century has impacted several hydraulic properties of flood flow. 
In authors' opinion the best solution is design where Krzywaniec reservoir is prepared to carry $\mathrm{Q}_{\max }=1100 \mathrm{~m}^{3} / \mathrm{s}$ with annual affluent rubble removal from reservoir bowl. The amount of removed rubble is calculated on 30 to 50 thousand $\mathrm{m}^{3}$. Heightening of the top of levee side barrier with preserving of present state of reservoir bowl at the same time (to regulate stand density on island, what has significant influence on flow WW) and regulation river-bed.

This solution is least expensive (estimated cost of construction work is about $12.6 \mathrm{mln}$ zf), moreover it is possible to enable dry-work using commonly available equipment.

One of the primary conditions of appropriate exploitation of reservoirs is correct assessment of the silting up process both in time and spatial aspect. To make a decision concerning reproduce initial condition on Krzywaniec reservoir have to take into consideration present environmental status. The choose conception of the Krzywaniec reservoir silting up is giving consideration to both economic and ecological conditions.

\section{REFERENCES}

GLOWSKI R., KASPEREK R., MOKWA M., PARZONKA W. 2004: Wstępna ocena transportu rumowiska wleczonego w Dolnym Bobrze, Zeszyty Naukowe Akademii Rolniczej we Wrocławiu, Inżynieria Środowiska XIII, nr 502, 101-107.

MOKWA M., GŁOWSKI R., KASPEREK R., PARZONKA W. 2004: Ocena procesu zamulania zbiornika wodnego Krzywaniec, Zeszyty Naukowe Akademii Rolniczej we Wroctawiu, Inżynieria Środowiska XIII, nr 502, 317-324.

Koncepcja odtworzenia warunków wyjściowych na stopniu Krzywaniec. Maszynopis Hydroprojekt. Wrocław 2005.
Operat wodnoprawny na prace inżynieryjne związane $\mathrm{z}$ oczyszczaniem i pogłębianiem zbiornika Krzywaniec, 1992. SURBUD Poznań. Maszynopis.

Studium regulacji rzeki Bóbr w cofce zbiornika Krzywaniec, 1985. Hydroprojekt Wrocław. Maszynopis.

Studium techniczne zabudowy rzeki Bóbr 0-124 na terenie województwa zielonogórskiego - Stopień Krzywaniec, 1990. Hydroprojekt Wrocław. Maszynopis.

Zbiornik Krzywaniecki w Hydrowęźle Dychów, 1997. Materiały Konferencji zorganizowanej przez Towarzystwo Elektrowni Wodnych, Dychów.

Streszczenie: Wplyw zamulania zbiornika Krzywaniec na jego przepustowość. Zbiornik Krzywaniec wchodzi w skład kompleksu hydrotechnicznego Dychów. Zbiornik powstał w wyniku spiętrzenia rzeki Bóbr w 42+700 km do rzędnej 73,30 NN. Dolina rzeki przegrodzona została trzyprzęsłowym jazem zasuwowym i śluzą wlotową do kanału derywacyjnego ESP Dychów. Obecnie zbiornik jest prawie całkowicie wypełniony rumowiskiem, stwarza to duże niebezpieczeństwo wystapienia powodzi na terenach przyległych. Przy aktualnym stanie zamulenia zbiornika Krzywaniec prawdopodobny poziom zwierciadła wody $\mathrm{Q}_{1 \%}$ ułoży się powyżej istniejących obwałowań, co może spowodować zalanie terenów chronionych. Zagrożona jest także eksploatacja jazu i Kanału Dychowskiego. Podczas zrzutu wielkich wód może dochodzić do zamulania kanału i koryta Starego Bobru oraz odkładów rumowiska pod zasuwami. Autorzy określili redukcje fali powodziowej w zależności od sposobu udrożnienia zbiornika, wykorzystując do tego celu symulacje komputerowe przeprowadzone w programie HEC-RAS.

\section{MS. received April 2008}

Authors' address:

Uniwersytet Przyrodniczy we Wrocławiu

Pl. Grunwaldzki 24, 50-363 Wrocław

Poland

e-mail:mokwa@ozi.ar.wroc.pl 